\title{
The role of the carbon monoxide in the ecology of wood-decomposing Hymenomycetes
}

\author{
Veikko Hintikka \\ Finnish Forest Research Institute Unioninkatu $40 \mathrm{~A}$ \\ SF-00170 Helsinki 17
}

\begin{abstract}
In the laboratory, decaying wood produces measurable quantities of carbon monoxide as measured with on infra-red gas analyzer. The highest CO concentration 205 ppm, was obtained from birch wood, colonized by Piptoporus betulinus. Pure cultures of wood-decomposing fungi grown on malt agar give a positive reaction with palladium chloride. The tolerance of 32 wood-decomposing species of Hymenomycetes was determined by growing them in desiccators, into which measured amounts of carbon monoxide were added. All species proved to grow well in 1:1 CO - air mixtures and most of them grew in 3:1 mixtures, suggesting that in the ecology of wood-decomposing fungi CO is of minor importance.
\end{abstract}

\section{Introduction}

The main natural supply of carbon monoxide is evidently to be found in the oceans, where among others certain algae accumulate this gas in their pneumatocysts (LANGDON 1917, Ghapman \& Tocher 1966). Small amounts of this gas arise also in many living processes, for instance in the decomposition of manure (WAKSMAN 1931) and in germinating seeds (CARR 1961). Carbon monoxide does not accumulate in greater quantities, evidently due to the fact that many organisms utilize $\mathrm{CO}$ readily, and natural soil is able to remove carbon monoxide rapidly from the air (INman et al. 1971).

Several investigations have shown that carbon dioxide accumulates within decomposing tree trunks, thus indicating more or less anaerobic conditions (e.g. Hintikka \& KorHONEN 1970). Under these conditions, incomplete oxidation may lead to the production of carbon monoxide, as this gas is supposed to be a byproduct of e.g. polyphenol (Loewus \& Delwiake 1963) or flavonoid (Westlake, Roxburgh \& Talbot 1961) metabolism.

\section{Experiments and Results}

Production of carbon monoxide in decaying wood and by wood-decompusing fungi.

1. Rotten wood colonized by different wood-decomposing fungi was collected in Ruotsinkylä Experimental forest, taken to the laboratory, and placed in desiccators (volume ca. 10 liters) and plastic barrels (volume ca. 30 liters). Both were kept in a windowless room at room temperature $(22$ $25^{\circ} \mathrm{C}$ ).

2. Pure cultures of wood-decomposing fungi, preserved in the Forest Biology Laboratory of the Finnish Forest Research Institute, were inoculated into 250 or $500 \mathrm{ml}$ erlenmeyer flasks containing 50 or $100 \mathrm{ml}$ of $1 \%$ Difco malt extract and $1.5 \%$ Difco 
bacto-agar in distilled water. The substrate was autoclaved for $20 \mathrm{~min}$ at $120^{\circ}$, inoculated without using a gas flame, sealed with sterilized rubber stoppers, and allowed to grow in a dark room for $1-2$ months. The volume of the closed gas space above the mycelium was ca. $175-400 \mathrm{ml}$.

Determinations were carried out by IR gas analyzer at the Institute of Occupational Health, Depart. of Air Pollution, Helsinki. The results are given in Table 1.

Table 1. Carbon monoxide (ppm) in the air in closed desiccators containing decaying wood.

Experiment 1, duration 131 days. ppm CO Wood from a decaying birch stump ... 51,0

Wood from a rotten spruce stump ..... 9. 9,4

Aspen branches, diameter $5-10 \mathrm{~cm} \ldots . .34,8$

Control ................ 3,2

Experiment 2, duration 42 days

Wood from a trunk of Betula, decomposed by Fomes fomentarius and Piptoporus betulinus (basidiocarps present) ......... Wood of Alnus glutinosa, decomposed by Ganoderma applanatum ............. Wood of Betula sp., infected with Poria

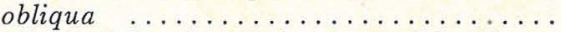
Wood of Betula sp., decomposed by Fomes

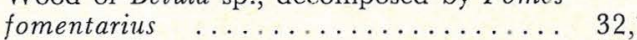
As preceding $\ldots \ldots \ldots \ldots \ldots \ldots \ldots \ldots \ldots \ldots \ldots \ldots$ Wood from a birch trunk taken from near basidiocarps of Piptoporus betulinus .... 205,0 Wood of Picea taken from near basidiocarps of Fomitopsis pinicola and Hirschioporus

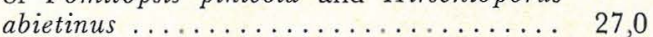

Controls . . . . . . . $\ldots \ldots \ldots \ldots \ldots \quad 7,1$

Preliminary determinations were made by the palladium chloride method of ALLEN and Root (1956). The gas to be analyzed was first purified by removing other reducing gases with activated charcoal. Definate precipitates were obtained from Fomes fomentarius, and Fomitopsis pinicola, the concentrations being at a $10-50 \mathrm{ppm}$ level. Some determinations were carried out by the iodopentoxide method, where carbon dioxide was first removed from the gas with $\mathrm{NaOH}$, the $\mathrm{CO}$ was then oxidized by $\mathrm{I}_{2} \mathrm{O}_{5}$, and the resulting $\mathrm{CO}_{2}$ was absorbed by $\mathrm{NaOH}$, and the amount of $\mathrm{CO}$ colorlated from the resulting increase in conductivity. These determinations were made at the Institute of Work Hygiene, with an Ultragas gas analyzer, made by Apparatenbau H. Wösthoff oHG, Bochum, Germany. The following values were obtained using this method: from cultures on malt agar: Fomes fomentarius $100-130 \mathrm{ppm}, F_{0}$ mitopsis pinicola 23-125 ppm, Hypholoma sublateritium $201 \mathrm{ppm}$ and Pholiota alnicola 219 ppm.

\section{Effect of carbon monoxide on the growth of wood-decomposing and soil-inhabiting Hymenomycetes in aseptic culture}

In order to evaluate the possible ecological effects of the concentrations of carbon monoxide found in closed cultures, fungus strains were grown aseptically in different $\mathrm{CO}$ : air mixtures.

Method. Fungus strains cultured in the Forest Pathology Laboratory of the Finnish Forest Research Institute, were inoculated on $1 \%$ Difco malt extract agar in 10 or $5 \mathrm{~cm}$ petri

Table 2. Effect of carbon monoxide on the radial growth (mm) of 29 wood- and litter-decomposing fungi on $1 \%$ malt extract agar.

Species per cent $\mathrm{CO}$ $0 \quad 1 \% 5 \% \quad 10 \% 25 \% 50 \% 75 \%$

\begin{tabular}{|c|c|c|c|c|c|c|}
\hline Clitocybe clavipes & 24 & 24 & 24 & 22 & 18 & 10 \\
\hline C. nebularis & 10 & 10 & 10 & 10 & 9 & 9 \\
\hline C. odora & 6 & 5 & 5 & 4 & 4 & 4 \\
\hline Collybia asema & 12 & 12 & 10 & 10 & 9 & 4 \\
\hline C. confluens & 13 & 12 & 12 & 12 & 8 & 1 \\
\hline C. dryophila & 18 & 14 & 18 & 15 & 18 & 4 \\
\hline Coriolus hirsutus & 29 & 29 & 28 & 24 & 13 & 1 \\
\hline Daedalea quercina & 14 & 13 & 12 & 12 & 12 & 8 \\
\hline Fomitopsis annosa & 27 & 32 & 28 & 25 & 15 & 5 \\
\hline F. pinicola & 19 & 21 & 21 & 21 & 18 & 10 \\
\hline Gloeophyllum & & & & & & \\
\hline sepiarium & 19 & 18 & 18 & 16 & 14 & 10 \\
\hline Hirschioporus & & & & & & \\
\hline abietinus & 9 & 3 & 9 & 3 & 6 & 1 \\
\hline Inonotus rheades & 15 & 15 & 15 & 14 & 12 & 7 \\
\hline $\begin{array}{c}\text { Kuehneromyces } \\
\text { mutabilis }\end{array}$ & & & & & & \\
\hline $\begin{array}{l}\text { mutabils } \\
\text { Marasmius }\end{array}$ & 12 & 12 & 12 & 11 & 7 & 4 \\
\hline androsaceus & 15 & 17 & 17 & 14 & 13 & 7 \\
\hline M. bulliardii & 24 & 24 & 24 & 22 & 18 & 10 \\
\hline M. perforans & 11 & 10 & 10 & 8 & 7 & 2 \\
\hline M.urens & 15 & 14 & 15 & 15 & 13 & 10 \\
\hline Mycena laevigata & 6 & 5 & 5 & 5 & 3 & 2 \\
\hline Phellinus igniarius & 12 & 13 & 13 & 13 & 10 & 9 \\
\hline P.pini & 7 & 5 & 5 & 5 & 5 & 1 \\
\hline Pholiota aurivella & 9 & 10 & 10 & 9 & 9 & 2 \\
\hline P. squarrosa & 8 & 6 & 6 & 6 & 5 & 2 \\
\hline Piptoporus & & & & & & \\
\hline betulinus & 19 & 18 & 18 & 14 & 13 & 6 \\
\hline Polyporus & & & & & & \\
\hline brumalis & 27 & 27 & 27 & 20 & 3 & 1 \\
\hline $\begin{array}{l}\text { Pycnoporus } \\
\text { cinnabarinus }\end{array}$ & 0 & 0 & 0 & ת & 10 & 1 \\
\hline $\begin{array}{l}\text { cinnabarinz } \\
\text { Stereum }\end{array}$ & & 20 & 20 & 20 & 13 & \\
\hline purpureum & 40 & 40 & 38 & 38 & 35 & 15 \\
\hline S. sanguinolentum & 6 & 6 & 6 & 6 & 4 & 2 \\
\hline Xeromphalina & & & & & & \\
\hline campanella & 9 & 9 & 9 & 9 & 9 & 8 \\
\hline
\end{tabular}




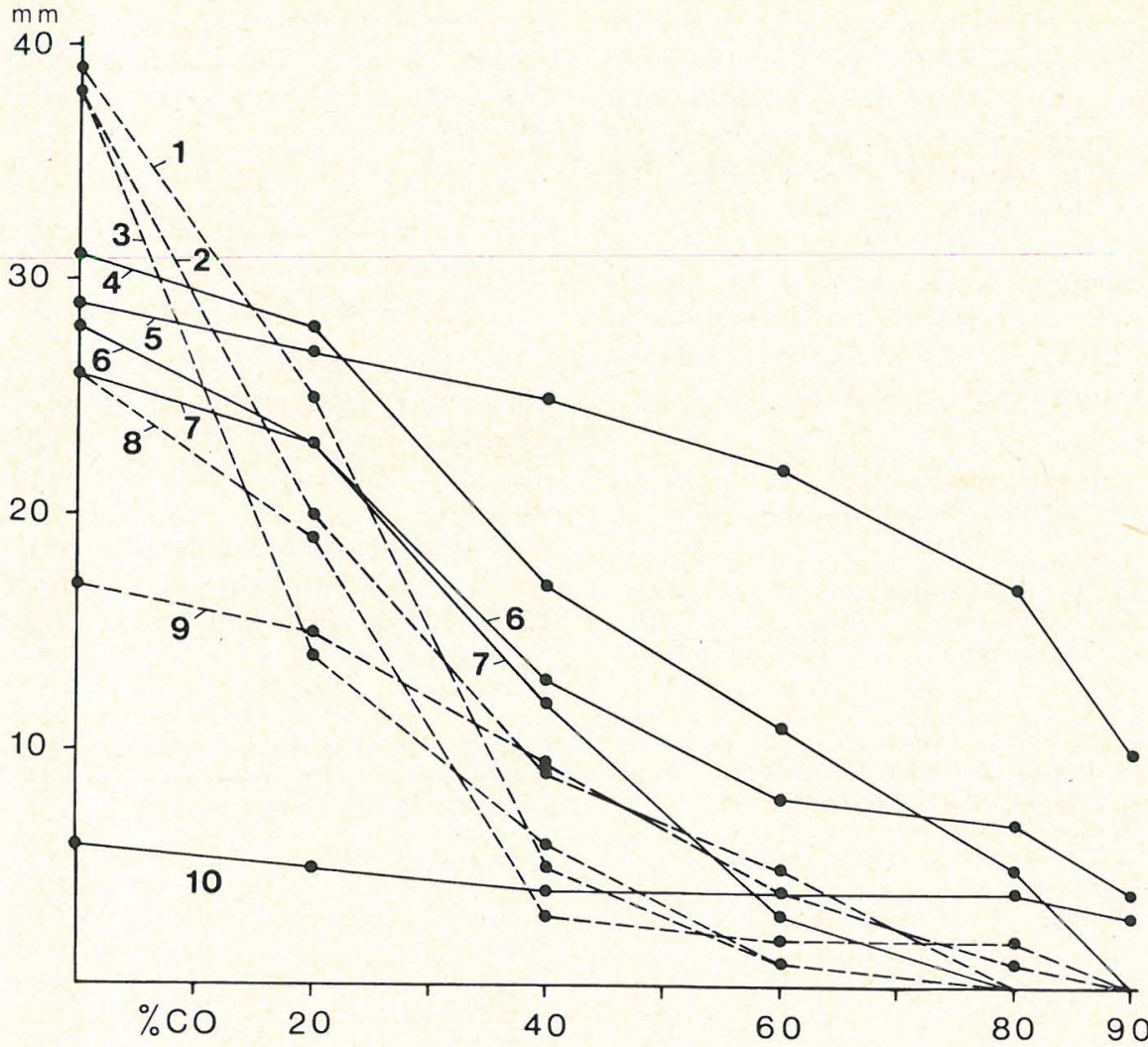

Fig. 1. Effect of carbon monoxide in the air on the radial growth ( $\mathrm{mm}$ ) of 5 white-rot fungi (- _ - ) and 5 brown-rot fungi (continuous line) on $1 \%$ malt extract agar. Duration of the experiment 8 days. 1: Corrolus hirsutus, 2: Fomes fomentarzus, 3: Polyporus brumalis, 4: Fomitopsis pinicola, 5: Laetiporus sulphureus, 6: Lentinus lepideus, 7: Piptoporus betulinus, 8: Pleurotus ostreatus, 9: Kuehneromyces mutabilis, and 10: Fistulina hepatica. On the average white-rot fungi were more inhibited by $\mathrm{CO}$ than brown-rot fungi.

dishes, which were placed upside down without lids in 5-10 l desiccators, which were then evacuated with a vacuum pump. Measured amounts of carbon monoxide gas prepared by Fluka Ag, Switzerland, »pure» grade, were drawn into the desiccators and the normal air pressure was reinstated. The short vacuum period did not effect the subsequent growth rate. After 9 or 10 days the radial growth was measured. The results are given in Table 2.

The brown-rot fungi (Fomitopsis pinicola, Gloeophyllum sepiarium, Daedalea quercina, Laetiporus sulphureus)in particular were extremely tolerant to carbon monoxide (Fig. 1). Certain white-rot fungi (Polyporus brumalis, Coriolus hirsutus) proved to be relatively by sensitive to this gas (inhibition occured at about $50 \%$ ).

\section{Discussion}

The present experiments indicate that within decomposing wood small amounts of carbon monoxide are evidently produced, probably due to the activity of wood-decomposing fungi. In view of the low concentrat- ions of $\mathrm{CO}$ and the high tolerance to this gas, it seems that in the fungal colonization of wood this gas is only of minor importance. Although the concentration in small cell cavities may be higher than in the present 
experiments, a rise to inhibiting levels seems improbable. As most of the species investigated still showed measurable growth in 3:1/ $\mathrm{CO}$ : air mixtures, it is evident that the main effect of carbon monoxide is as an asphyxicant through replacing the oxygen (ZIMMERMAN 1935). The inhibition of cytochrome and polyphenol oxidases occurs mainly above a value of 18:2 $\mathrm{CO}: \mathrm{O}_{2}$, which corresponds approximately to $75 \% \mathrm{CO}$ in air. $\mathrm{CO}$ is extremely toxic only to such animals where oxygen transport takes place by means of hemoglobin, and for man the toxic limit is about 1000 ppm. Accumulation approaching toxic levels in rotten wooden buildings seems also less probable. It is possible that the CO produced within the wood is oxidised of the surface in aerobic conditions, although this question needs additional experiments.

\section{Acknowledgements}

The author acknowledges with gratitude the technical assistance of Mr. KarI KORHOnen, Cand. Phil., and Miss Ritva Klemetti as well as the financial support from the Finnish National Board of Agriculture and Forestry.

\section{REFERENGES}

Allen, T. H. \& W. S. Root, 1956: Colorimetric determination of carbon monoxide in air by an improved palladium chloride method. Journ. Biol. Chem. 216, 309-317.

CARR, D. J., 1961: Chemical influences of the environment. - Encyclop. of Plant Phys. XVI, $737-794$.

Chapman, D. J. \& R. D. Tocher, 1966: Occurrence and production of carbon monoxide in some brown algae. - Can. J. Bot. 44, 1438.

Hintikka, V. \& K. Korhonen, 1970: Effects of carbon dioxide on the growth of lignicolous and wood-inhabiting hymenomycetes. Comm. Inst. Forest. Fenn. 69.5, 1-29.

Inman, R. E., R. B. Ingersoll \& E. A. Levy, 1971: Soil: A Natural sink for carbon monoxide. - Science 172, 1229-1231.
Langdon, S. C., 1917: Carbon monoxide occurrence free in kelp (Nereocystis luetkeana). - J. Am. Chem. Soc. 39, 149-156.

Loewus, M. \& C. C. Delwicke, 1963: Carbon monoxide production by algae. - Plant Physiology 38, 371-374.

Waksman, S. A., 1931: Principles of soil microbiology. - London. 1035 pp.

Westlake, D. W. S., J. M. Roxburgh and G. TALBot, 1961: Microbial production of carbon monoxide from flavonoids. - Nature $189,510-511$.

Wilks, S. S., 1959: Carbon monoxide in green plants. - Science 129, 964-966.

Zimmerman, P. W., 1935: Anaesthetic properties of carbon monoxide and other gases in relation to plants, insects and centipedes. - Contr. Boye Thompson Inst. 7, 147-155. 